\title{
På menneskejagt i Det kongelige Bibliotek
}

af Birte Ludovica Rasmussen

Under arbejdet med en anden opgave lagde jeg en dag mærke til to fede små bind, der skilte sig ud fra de andre bøger på min yndlingsreol med biografiske leksika. Samling af larde Fruentimer, Bd. I og II, stod der på ryggen af dem. Dem måtte jeg ubetinget se nærmere på ved først givne lejlighed!

Nogle dage senere var øjeblikket kommet. Jeg tog værket hen under min grønne lampe til nærmere eftersyn. Dets fulde navn var lovende Samling af danske lorde Fruentimmer (her med to m'er), som ved deres Lardom og udgivne efterladte Skrifter have gjort deres Navne i den lerde Verden bekiendte, med adskillige mest historiske Anmerkninger forøget og udgivet. Forfatteren hed Frederik Christian Schönau, og udgivelsesåret var 1753 .

Bind I indledes med et pompøst forord på 30 sider holdt i tidens mest svulstige stil. Den rare, men drikfældige og evigt-utro Frederik V får følgende karakteristik: „Ei engang tusende Tunger kunne værdelig indbefatte ... saa prisværdig en Konges forundringsværdige Dyder. "Schönau prøver dog alligevel trods påberåbelse af sine „ringe Gaver og sin liden Styrke i Veltalenhed ... og en upyntet (!) Stil“ som han „erkender alt for vel.“ Af disse grunde kan han ikke „fremføre noget værdigt og stort nok“ til at beskrive „den allerværdigste Konge Jorden kan eie ...“

Efter dette forord, der tager hele det kongelige hus under behandling, følger en 116-sider lang indledning rettet til den tålmodige læser.

Beretningen om de damer, han har kastet sig over, er skuffende. Det er tydeligt, at forfatteren ikke er nær så optaget af deres lærdom som af sin egen. Flere sider i træk står der kun to - måske tre - linier om den aktuelle lærde kvinde. Resten er 
vidtløftige noter og strøtanker, som den belæste Schönau åbenbart brænder efter at få anbragt.

Sidst i bind I (på side 757) erklærer han endda frejdigt, at mange kvinder uden ret blev kaldt lærde, fordi tidens mode krævede det af alle "Frøkener og Damer“. Nogen skød genvej ved at læse lidt her og der, mens andre endda betalte sig til et forfatterskab af en mindre kendt skribent. Biografierne bringes i alfabetisk orden, da en opdeling efter „virkelig lærd og halvlærd“ ville have voldt „Fortræd, Ulejlighed, Had og Bagtalelser".

Bogen fremkom - som han skriver i forordet: „Den 9. Martii paa min FødselsDag Aar 1752 i min Alders 24ende Aar“", og han bekendtgør samme sted, at der er mere på trapperne. Han agter at skrive om lærde danske mænd og en traktat om „Kvindekønnets Beqvemhed til Studeringer.“ Men ingen af de stolte planer blev realiserede, så vi kan kun gætte os til, hvorvidt han fandt kvinder studieegnede.

Værket blev hans sidste udgivelse. Hvorfor opgav denne skriveglade og energiske mand med eet slag sit forfatterskab? Det virker mærkeligt. Hvem er den mand?

Tilbage til yndlingsreolen. R. Paulli fortæller om ham i Dansk Biografisk Leksikon fra 1983. Det viser sig, at manden havde en helt speciel baggrund som søn af Frederik V's amme, parykmager Schönaus kone, fru Cathrine Elisabeth født Buus. ${ }^{1}$ Hun må have røgtet sit hverv med ære. Ihvertfald viste Frederik sig senere meget nådig overfor parrets fem år yngre søn med de royalistiske fornavne. Ikke alene betalte han drengens skolegang, så han kunne få studentereksamen som privatist. Han støttede også den unge mands litterære udgivelser i den korte årrække, han udfoldede sig som forfatter og oversætter.

Derved blev det muligt for ham at udgive dels oversættelser, dels egne arbejder hurtigt efter hinanden uden at bekymre sig om økonomien. Måske gik det lidt for let. Hans selvfølelse var enorm og stod i omvendt forhold til taktfølelsen. Sandsynligvis havde klassekammerater i en latinskole kunnet bremse ham lidt ved hjælp af små-ironiske bemærkninger på rette sted og nogle skæve grin, når han blev for storagtig? Men den slags støtte blev ham ikke til del som ensom privatist.

Men myreflittig var han. Det står fast. Han studerede samtidig hele syv forskellige videnskabelige områder fra jura til oldtidskundskab. Som kun 18-årig udgav han en oversættelse af Persius til skolebrug, og derefter gik det slag i slag. Skulle der lægges penge på bordet, var Frederik $\mathrm{V}$ altid parat til at linde på den kongelige chatolkasse. 
Ved en vis lejlighed greb majestæten endda personligt ind: Schönau havde oversat Phadri Fablerog havde gavmildt forsynet den med egne filologiske betragtninger. Tilføjelserne faldt dog ikke i sagkundskabens smag, og man modsatte sig en udgivelse. Kongen tillod imidlertid, at bogen måtte forhandles - dog ikke som skolebog.

C.L. Baden, der i årbøger beskrev „Danmarks og Norges Kong Frederik V’s Regering“, omtaler 1832 side 87 kongens protegé som „den mindre lærde end flittige“!

Mange af den flittiges meriter beskrives af P.M. Stolpe i Pressens Historie side 148. Den er nævnt under Schönau-artiklen i Biografisk Leksikon. Pressehistorikeren lægger ikke fingre imellem i sin omtale af vor ven. Han fortæller, at Schönau 21 år gammel udgav et prøvenummer af en Journal over danske Bøger, saavel gamle som nye. Blandt indholdet fandtes en artikel om lærde Journalers nytte og deres skæbne i Danmark ... efter sigende et plagiat af en 12 år gammel artikel. Journalen fik selv en krank skæbne. Det blev ved prøvenummeret!

Frederik Christian var slem til at fælde hastige domme og sparede ikke på kritik af andre. Dertil kom, at datidens polemiske sprogbrug var alt andet end sart. Det var ikke uden grund, at Kiøbenhavnske nye Tidender for Larde og Curieuse Sager gjorde opmærksom på, at ganske vist stod bladets spalter åbne for indsenderes stof, „dog ikkun saa længe, som de bruge en Skrive-Maade, som er Lærde anstændig“ ... en formålsparagraf, som Schönau skulle få vanskeligheder med.

I disse gæstfri spalter kritiserede han nådesløst en oversætterkollega, Christen Schmidt, der havde oversat og udgivet en levnedsbeskrivelse af Luther og hans udlægning af I. Mosebog. Schmidt bed fra sig, og polemikken blev så indædt, at en harmfuld læser i bladets juninummer 1750 opfordrede de herrer til „aldrig mere at lade deres Navne se paa Prænt, førend de havde forbedret deres Smag ..."

Bagest i samme nummer af bladet bekendtgjorde Schönau at han „efter mange Lærde og curieuse Folks Raad“ stopper polemikken her og i stedet agter at udgive hele diskussioen i en „aparte Piece“. På den måde lagde han et røgslør over den flove kendsgerning, at Lerde Tidender havde frabedt sig flere bidrag. Man fandt ikke skrivemåden anstændig disse lærde imellem.

Fire år senere bragte bladet side 92 en undskyldning fra Schönau, som universitetet havde krævet af ham: „I Anledning af den Artikel om de akademiske Grader, som er indført i min Samling af Danske Lærde Fruentimmer, hvilken haver foraarsaget Fortrydelse hos vedkommende, erklærer jeg herved frivilligen og oprigtigen 
og offentligen, at jeg i bemeldte Artikel aldeles ikke haver ment det højlovlige Universitet i Kiøbenhavn eller promotioner ved samme“. Han henviser til, at en række professorer, blandt andet Holberg, havde kritiseret udenlandske universiteter ,... og hvis jeg af uforsigtighed imod min Hensigt haver fulgt for nøye disse Skribentere, er jeg derover ført paa Afveje “. Anstødsstenen var en bemærkning om universitetets - efter hans mening - kritisable tildeling af akademiske grader. Sådan former man en undskyldning, når man er Frederik Christian Schönau!

Mange år senere læste forfatteren Carl Dumreicher fruentimmerbogen og fandt i notevrimlen ,intet mindre end den første Afhandling om Romanen som litterær Kunstform “. Dens litteraturhistoriske Stilling og Synspunkter gjorde den værdig til at udgives som selvstændig Publikation, mente han og udgav den i 1941 som et lille skrift på kun 22 sider: En kort Afhandling om Romaner af Fr. Chr. Schönau.

Dumreicher indleder med nogle ord om forfatteren og giver sandsynligvis her (på side 4) svaret på, hvorfor den begavede unge mand forsvandt fra det litterære parnas. Han gør opmærksom på et klodset tiggeri, der findes midt i fruentimmerbogens sirlige fortale. Først takker Schönau Majestæten for allernådigst at have skænket „,noget anseeligt“ til støtte for udgivelsen, men siden spiller han på muligheden for at modtage flere og større nådesbevisninger „til min Lysts Fornyelse og Bestandighed med flere Skrifter at zire mit Fædreneland ..."

Var tiggeriet for tydeligt, spørger Dumreicher. I hvert fald kom der ikke flere skrifter til pryd for fædrelandet. Romannoten går fra side 939 til side 960 og knytter sig til en vis Margrethe Lassen og til hendes bog Den bekladte Sandhed, som var udkommmet i 1723. „Et meget net og zirligt Skrift paa Dansk, som er en Roman“, skriver Schönau side 137-38. Den lange og interessante note behandler både romanens historie gennem tiderne, denne specielle roman og overvejelser om, hvorvidt læsning af romaner kan være af værdi. Hans samtidige, Holberg, fordømte romanformen. Han kunne ikke se, hvad Schönau indså, at romanen kunne have beretttiget værdi som selvstændigt digterværk. Schönau holdt på, at en god roman kunne styrke læserens moral og sætte hans sind i bevægelse. Andre havde før ham peget på læsningens pædagogiske værdi, men „det æstetiske Synspunkt er Fr. Chr. Schönaus egen betydningsfulde Indsats“, understreger Dumreicher på side 5. Måske ligger der flere guldkorn gemt i det bindstærke værks uoverskuelige noter? Det havde været rart at kunne fortælle om flere positive udslag af denne mærkelige 
mands omfattende studier og store skrivelyst.

Men der blev stille omkring ham, og tre år efter fremkomsten af hovedværket om kvinderne søgte han tilbage til barndommens Århus og blev residerende kapellan ved domkirken ... måske hjulpet til embedet af sin allernådigste konge? Det er fristende at tro på protektion, for først efter sin ansættelse blev han teologisk kandidat!

Var han så en åndfuld og inspireret præst, der blandt andet hentede inspiration fra sin omfattende læsning? Jeg leder efter oplysninger i Peter Friedrich Suhms samlede Skrifter, 5. del.

Suhm var bogsamler i stort format, historiker og forfatter. Han var gift med en norsk dame og sad som ærværdig etatsråd i Tronhjem. Herfra korresponderede han bl.a. med magister Benjamin Dass som havde været rektor i Tronhjem, men som nu boede i København.

15. februar 1755 fortæller Dass om Schönaus planer. Han vil efter sigende omskrive fruentimmerbogen og tage nogen af noterne ud. „En Hoben af det forrige Lapperie skal han ville undlade; men jeg mener, vi faae nok ligesaa meget derind igien“. Dass tilføjer: „Jeg har ei selv læst det Rageri“.

Den 2. august samme år rapporterer han: „Schönau er nu blevet Capellan i Aarhus ... om han nu herefter vil skrive mere eller mindre, vil Tiden vise; imidlertid frygter man her for, at vor lærde Republik vil lide et stort Tab!“ At kalde kongeriget for en republik kan hentyde til Frederik V's tilbøjelighed til at overlade regeringsansvaret til fremtrædende politikere. Med hensyn til 'Tabet' er ironien ikke til at tage fejl af.

Den 2. oktober må Schönau igen holde for. Dass skriver: „Hr. Schönau har endelig faaet Attestats med Characteren contemmendo". Prædikenen var i hans kritiske ører „saa miserablement, at Faa kunde høre noget, og det man hørte, duede intet, saa han endnu er slettere Prædikant end Skribent, eller maaske lige god i begge Dele“.2

Dass har nok smurt lidt tykt på, men de videre data er ikke glorværdige. I syv år skrev unge Schönau som en rasende. Han havde endog bedyret, at hans ,utrættelige Flid" aldrig skulle trættes, saa længe Blodet rørte sig i hans Årer. Blodet cirkulerede stadig, men med forfatterskabet var det slut uden forklaring.

Samtidig med embedet ved Århus domkirke var han præst ved hospitalet og i Åby; elleve år senere blev han sognepræst i Kregme-Vinderød. I dette embede døde - han kun 44 år gammel efter at have været enkemand i godt fire år. Han steg ikke i graderne trods sine medfødte gode evner. Sandsynligvis har han følt sig miskendt; 
men nogen habil forvalter af samme evner har han nu ikke været!

Et oldebarn, Conradine Bruhn født Schönau, har udgivet en lille slægtsbog, Erindringer og Oplevelser, 1916. Paulli henviser til den i Dansk Biografisk Leksikon ${ }^{3}$, og jeg bestiller den til læsesalen gennem bibliotekets herligt hjælpsomme telefontjeneste. Optimistisk tror jeg, at Conradine vil fortælle en masse mere om Frederik Christian, men nej, hun helliger sig mest sin mors familie og forarger mig ved i forbindelse med oldefaderen ikke at nævne hans ungdoms forfatterår eller hans 'allerværdigste’ protektor. Derimod nævner hun hans allerførste (og forbigående) embede som kateket ved en fattigskole. Så springer oldebarnet flot frem til kapellanstillingen i Århus!

Til gengæld får man at vide, at han giftede sig med Johanne Marie Müller og at parrets barn, Johan Frederik, blev politimester i Hobro og velsignedes med 11 sønner. Slægten blev med andre ord ført livskraftigt videre.

Også en slags happy ending.

1) Det mærkelige er, at amme-prinsen er født fem år før Frederik Christian, og ægteparret har tilsyneladende kun haft ét barn. En slags forklaring finder jeg på Rigsarkivet i Roeds register over hofetaten. Der står C.E. Buus opført som amme for Kronprins Frederik (V) n. 1724 sg. 1726. Det tolker jeg som at prinsen var et år gammel, da hun tiltrådte, og tre år, da amningen hørte op. Var parykmageren måske også på lønningslisten? Ja, han figurerer dels på et selvstændigt kort som parykmager, dels under „B“" med oplysning om, at han ca. 2. april blev gift med C.E. Buus.

Jeg gætter på, at de to har lært hinanden at kende i de kongelige omgivelser, hvorefter meget taler for, at det barn, der gjorde det muligt for Cathrine Elisabeth at blive amme, er født som illegitimt i 1723 uden Johans medvirken - hvad der så ellers er blevet af barnet?
2 ) Norsk Biografisk Leksikon har meget at sige om Benjamin Dass. Han levede fra 1706 til 1775 og havde „megen sans for vid og satire ... D's sarkasmer kunne let forfærde hver den, som ikke kjendte ham nærmere“. Det noteres, at han helt fra sin ungdom var en trofast beundrer af Ludvig Holberg ... som Schönau jo dels hængte ud i sin såkaldte 'undskyldning' og dels imødegik med sit syn på romanen. Alt i alt tager disse oplysninger jo til en vis grad noget af den skarpe brod i Dass' nedgørelse af Schönau.

3 ) I Jens Worms Leksikon over larde Mand, bd. 2, finder man også Frederik Christian. Worm skriver: „1743 blev han af mig efter foregaaende privat Information til Academiet dimitteret“". Desværre nåede han ikke at glæde sig over, at professoren optog ham blandt sine lærde. Leksikonudgivelsen kom 1773, året efter hans død ... hvad Worm ikke nåede at registrere. 